NBER WORKING PAPER SERIES

EMPLOYEE FINANCIAL LITERACY AND RETIREMENT PLAN BEHAVIOR: A CASE STUDY

\author{
Robert Clark \\ Annamaria Lusardi \\ Olivia S. Mitchell
}

Working Paper 21461

http://www.nber.org/papers/w21461

\author{
NATIONAL BUREAU OF ECONOMIC RESEARCH \\ 1050 Massachusetts Avenue \\ Cambridge, MA 02138 \\ August 2015
}

Research support for the work reported herein was provided by the Pension Research Council/Boettner Center at the Wharton School of the University of Pennsylvania as well as the Office of Employee Benefits at the Federal Reserve System that provided the data for the study and partial funding for the project. We are grateful for excellent programming assistance from Yong Yu, and for helpful suggestions and guidance from the staff of the Federal Reserve's Office of Employee Benefits and Ryan Peters. Opinions and conclusions expressed herein are solely those of the authors and do not represent the opinions or policy of the funders or any other institutions with which the authors are affiliated. The views expressed herein are those of the authors and do not necessarily reflect the views of the National Bureau of Economic Research.

At least one co-author has disclosed a financial relationship of potential relevance for this research. Further information is available online at http://www.nber.org/papers/w21461.ack

NBER working papers are circulated for discussion and comment purposes. They have not been peerreviewed or been subject to the review by the NBER Board of Directors that accompanies official NBER publications.

(C) 2015 by Robert Clark, Annamaria Lusardi, and Olivia S. Mitchell. All rights reserved. Short sections of text, not to exceed two paragraphs, may be quoted without explicit permission provided that full credit, including (C) notice, is given to the source. 
Employee Financial Literacy and Retirement Plan Behavior: A Case Study

Robert Clark, Annamaria Lusardi, and Olivia S. Mitchell

NBER Working Paper No. 21461

August 2015

JEL No. D91,J26,J32,J33

\begin{abstract}
$\underline{\text { ABSTRACT }}$
This paper uses administrative data on all active employees of the Federal Reserve System to examine participation in and contributions to the Thrift Saving Plan, the system's defined contribution (DC) plan. We have appended to the administrative records a unique employee survey of economic/demographic factors including a set of financial literacy questions. Not surprisingly, Federal Reserve employees are more financially literate than the general population; furthermore, the most financially savvy are also most likely to participate in and contribute the most to their plan. Sophisticated workers contribute three percentage points more of their earnings to the DC plan than do the less knowledgeable, and they hold more equity in their pension accounts. Finally, we examine changes in employee plan behavior a year after the financial literacy survey and compare it to the baseline. We find that employees who completed an educational module were more likely to start contributing and less likely to have stopped contributing to the DC plan post-survey.
\end{abstract}

Robert Clark

Poole College of Management

Box 7229

North Carolina State University

Raleigh, NC 27695

and NBER

robert_clark@ncsu.edu

Annamaria Lusardi

The George Washington University

School of Business

2201 G Street, NW

Duques Hall, Suite 450E

Washington, DC 20052

and NBER

alusardi@gwu.edu
Olivia S. Mitchell

University of Pennsylvania

The Wharton School

3620 Locust Walk, St 3000 SH-DH

Philadelphia, PA 19104-6302

and NBER

mitchelo@wharton.upenn.edu 


\title{
Employee Financial Literacy and Retirement Plan Behavior: A Case Study
}

\author{
Robert Clark, Annamaria Lusardi, and Olivia S. Mitchell
}

Most Americans score quite poorly on financially knowledge tests (Lusardi and Mitchell, 2014). This reality is prompting many employers to provide financial education to their workers, because financially-stressed employees are widely seen to be less productive. ${ }^{1}$ Moreover, many large firms with DC plans offer financial education programs believing that giving people financial knowledge can enhance their retirement saving. ${ }^{2}$ In this paper, we report results from a case study of employees of the US Federal Reserve (FR) system, to evaluate how knowledgeable these employees are about personal finance and to explore whether this knowledge is associated with more retirement saving in the employer's defined contribution (DC) plan.

We link administrative records provided by the Office of Employee Benefits of the Federal Reserve System (OEB) to a survey we fielded inquiring about employees' financial literacy. The linked data allow us to draw some conclusions about the saving and investment patterns of the more- versus less-financially literate segments of employees. Finally, we examine changes in employee DC plan behavior a year after completion of an educational module that included our financial literacy survey and compare it to the baseline.

\footnotetext{
${ }^{1}$ A recent report by the Consumer Financial Protection Bureau (2014) offers numerous citations on the productivity/financial stress nexus.

${ }^{2}$ Studies on workplace financial education programs include Bernheim and Garrett (2003); Bayer, Bernheim, and Sholz (2009); Clark, d'Ambrosio, McDermed, and Sawant (2006); and Clark, Morrill, and Allen (2012a, b; 2014). For a review, see Lusardi and Mitchell (2007, 2014).
} 
We find that a high fraction (84 percent) of FR employees participates in and contributes to the DC plan offered by the FR. As in other work, we show that marital status, salary, tenure, and financial literacy are all predictors of participation in the retirement saving plan, while contribution levels to the firm's DC plan are influenced by age, salary, and financial literacy. FR workers' levels of financial literacy are also quite high compared to the general population, though we can measure this for only a subset of workers. More financially knowledgeable employees are also much more likely to participate in their retirement saving plan, contribute more of their salaries, and hold more equity in their DC retirement accounts. Nevertheless areas for improvement remain.

\section{Data and Methods}

We focus on three measures of DC plan behavior: contributions, the percent of salary contributed by those making active contributions to the plan, and portfolio allocations by plan participants. These are available from administrative records on over 21,000 FR employees across the U.S. who were employed in April 2013. The Federal Reserve system offers its employees the opportunity to participate in a DC plan having a fund menu that includes stock and bond index choices, target date bond funds, lifestyle funds (conservative, moderate, aggressive), international and emerging market funds, and a real estate fund. ${ }^{3}$

The OEB provided us with (anonymized) administrative records on each employee's contribution rates and investment allocations across the fund menu as of April 2013. In cooperation with the OEB, we also fielded an internet survey on financial knowledge in October 2013. Under confidentiality conditions, employees' responses were linked to administrative

\footnotetext{
${ }^{3}$ Employees are also covered by a relatively generous defined benefit (DB) pension. We do not have measures of their DB pension wealth, but we can control for each employee's age and tenure which are good proxies for a FR employee's DB wealth value.
} 
records on peoples' contributions and investment allocations prior to the survey, along with their personal characteristics (including sex, age, marital status, job tenure, salary, and DC plan balances). Those who participated in the internet survey also received an educational module on the employer's benefits offerings. ${ }^{4}$ We used this merged data set to estimate the relationships between financial literacy and retirement saving decisions, as well as employees' responses to the survey/module.

\section{Measuring Financial Knowledge}

With our input, the OEB designed and fielded an online survey on the financial knowledge levels of its employees, inviting them to participate via the internet. Out of approximately 21,000 active workers, 16 percent responded to the invitation to take the survey and do the educational module in September of 2013. This response rate is similar to those from other voluntary and non-incentivized internet surveys. ${ }^{5}$

We use this administrative database to compare the survey/module respondent sample with the nonrespondent group. The first column of Table 1 presents means for all 2013 employees while Columns 2 and 3 entries are means for individuals who did not complete the educational module and those that did respectively. Since some of our analysis employs only the survey sample, comparing Columns 2 and 3 allows us to see how the survey sample differs from those who chose not to complete the educational module. Over two-thirds of all employees

\footnotetext{
${ }^{4}$ The objective of the educational module was to help workers assess retirement spending needs; key aspects of the DC plan (including the retirement provisions, vesting rules, contribution and payout options); and how Social Security and personal saving as well as the employer's retirement offerings interact.

5 This response rate is in line with what is found in many other online, nonmandatory, and nonincentivized surveys (c.f., Clark, Maki, and Morrill (2014); Constant Contact http://support2.constantcontact.com/articles/FAQ/2344; Benchmark http://www.benchmarkemail.com/help-FAQ/answer/what-is-a-typical-survey-response-rate; Surveygizmo, http://www.surveygizmo.com/survey-blog/survey-response-rates/ ).
} 
contribute to only to the pretax plan compare to eight percent who participate only in the Roth option. Interestingly, about nine percent contribute to both types of plans. Comparing the survey sample to those who did not complete the module we see that respondents contributed 2.0 percentage points more of their pretax salaries to the DC plan. ${ }^{6}$ Additionally, they had significantly higher plan balances, held 2.5 percentage points more equity, were about four years older, and had worked for the institution about three years longer than their non-responsive counterparts. It is likely that the employees who participated in the survey/module are likely to be more financially sophisticated than those who did not, a point we return to below.

\section{Table 1 here}

We measured respondent financial knowledge using five questions that have been tested in other surveys (correct answers are provided in bold):

- Interest Rate: Suppose you had $\$ 100$ in a savings account and the interest rate was 2\% per year. After five years, how much do you think you would have in the account if you left the money to grow? More than \$110, Exactly $\$ 110$, Less than $\$ 110, D K, R F^{7}$

- Inflation: Imagine that the interest rate on your savings account was $1 \%$ per year and inflation was $2 \%$ per year. After one year, how much would you be able to buy with the money in this account? More than today, Exactly the same, Less than today, DK, RF

- Risk: Is this statement True or False? Buying a single company's stock usually provides a safer return than a stock mutual fund. True, False, $D K, R F$

- Tax Offset: Assume you were in the 25-percent tax bracket (you pay $\$ 0.25$ in tax for each dollar earned) and you contributed $\$ 100$ pretax to an employer's 401(k) plan. Your take-home pay (what's in your paycheck after all taxes and other payments are taken out) will then: Decline by $\$ 100$, Decline by $\$ 75$, Decline by $\$ 50$, Remain the same, DK, RF

- Match: Assume that an employer matched employee contributions dollar for dollar. If the employee contributed $\$ 100$ to the $401(\mathrm{k})$ plan, his account balance in the plan including his contribution would: Increase by $\$ 50$, Increase by $\$ 100$, Increase by $\$ 200$, Remain the same, $D K, R F$

The first question measures people's ability to do a simple interest rate calculation; the second tests people's understanding of inflation; and the third is a joint test of knowledge about "stocks"

\footnotetext{
${ }^{6}$ Allen, et al (2013) also find that participation in retirement seminars significantly increase the financial literacy and knowledge of retirement plans of older workers and that this increased knowledge affects retirement plans.

${ }^{7}$ DK refers to "Do not know" and RF to "refuse to answer."
} 
and "stock mutual funds" as well as risk diversification, since the correct response requires the respondent to know both what a stock is and that a mutual fund is comprised of many stocks. The first three questions were developed by Lusardi and Mitchell (2008; 2011a) and used in the Health and Retirement Study and many other US national surveys including the National Longitudinal Survey of Youth (Lusardi, Mitchell and Curto, 2010), the American Life Panel (Lusardi and Mitchell, 2009), and the US National Financial Capability Study (Lusardi, 2011; Lusardi and Mitchell, 2011b). They have also been fielded in many other countries (Lusardi and Mitchell, 2011c, 2014). The last two questions were used in surveys fielded in large firms by Clark, Maki and Morrill (2014).

Our prior research has demonstrated that very few Americans can answer all of the first three questions correctly (with similar results in other countries). Not many more know the correct answers to a majority of the three (Lusardi and Mitchell, 2014). By contrast, the Federal Reserve workforce is substantially more financially knowledgeable (as measured by the first three queries) than the general population, an unsurprising result given that the group consists of financial sector employees. Specifically, 75 percent of the respondents answered the Interest Rate question, 91 percent the Inflation question, and 85 percent the Risk question correctly. This can be compared to lower correct response rates in other surveys; for example, 69 percent, 87 percent, and 71 percent correct responses, respectively, to the interest, inflation, and risk diversification questions in the 2012 National Financial Capability Study. ${ }^{8}$

The last pair of financial knowledge questions, developed by Clark, Maki, and Morrill (2014), prove more difficult - even for this relatively-sophisticated group. These queries require respondents to understand how employer and employee contributions influence pension

\footnotetext{
${ }^{8}$ The latter is also an online survey; see http://www.usfinancialcapability.org/downloads/NFCS_2012_Report_Natl_Findings.pdf
} 
accumulations, taking into account the tax implications of worker pre-tax contributions. In the Tax Offset question, the employee needs to understand that the tax-deferred aspect of own contributions reduces the net cost of payments into the plan. Here, only 43 percent of respondents answer correctly. The Match question requires the employee to know that a dollarfor-dollar match means that $\$ 100$ of own contributions would generate an equal employer contribution; moreover employer match dollars are not taxed when contributed to the plan. This last question is easier to answer for this population, and 76 percent score correctly.

As is conventional, we sum the correct answers to these questions to produce a Financial Knowledge Index for each employee respondent. This Index ranges from 0 to 5, with a mean of 3.7 and a standard deviation of 1.2. ${ }^{9}$ One-third of the group answered all five questions correctly, and just under two percent (46 respondents) cannot answer any question correctly. The proportion answering each question correctly is shown in Table 2 along with the average number of correct answers.

Table 2 here

\section{Baseline Analysis}

We turn next to the determinants of pension participation and the role of financial literacy. Table 3 reports the results of three regression models where the dependent variable is equal to one if the employee contributes to any of the employer's defined contribution plans (and 0 otherwise) as of April 2013, before our financial knowledge survey. The first two columns of the table report results using the full sample of all current employees, whereas the third column

\footnotetext{
${ }^{9}$ Inasmuch as respondents to the survey/module are more likely to be financially knowledgeable than nonrespondents, we would infer that the average level of financial literacy for the entire FR labor force is likely to be lower than the respondent average.
} 
uses only those individuals who completed the financial literacy survey and educational module. These regressions allow us to explore the determinants of participation and contribution to the DC plan, taking many factors simultaneously into account.

\section{Table 3 here}

Results from the full sample in Column 1 show that 84 percent of the FR employees contribute to their plan. There are also differences by worker characteristic: men are 2.0 percentage points less likely to contribute to a plan compared to women and each year of job tenure increases the probability of contributing to a plan by 0.8 percentage points. Consistent with our prior research, we also find that those with higher earnings, and individuals who are married, are more likely to participate in the DC plan (Clark, Maki and Morrill, 2014). Column 2, also for the full sample, presents estimated coefficients from a larger model which adds an indicator variable taking the value of one for employees who participated in the later financial literacy survey/educational module (and 0 otherwise). Inclusion of this variable in the model has no significant impact on the other variables in the regression, but it does show that survey respondents are 6.3 percentage points more likely to contribute to the DC plan. Evidently those who elected to take the survey differ from their less compliant counterparts.

Column 3 reports estimates from a similar model where we narrow the sample to only those persons who completed the financial literacy survey/educational module. In addition to the variables included in Column 1, two variables showing respondents' level of financial literacy are included in this model. One is an indicator for high financial knowledge (i.e., anyone who got 4-5 questions correct) versus medium (2-3 questions correct) versus the reference category (0-1 question correct). Our estimates indicate that the more financially savvy employees are also much more likely to contribute to the DC plan, and the estimated coefficients are strongly 
positive and statistically significant. The magnitudes imply that a worker scoring 4-5 correct answers is 13.4 percentage points more likely to be contributing to the plan, while someone scoring 2-3 answers correct has a 6.8 percentage points higher probability of contributing, compared to the least financially-savvy employee. ${ }^{10}$

Next we examine plan contribution rates, expressed as a percent of salary. Across the full sample of plan participants, the contribution rate averages 8.7 percent; see Table 4 . Columns 1 and 2 again focus on all employees, while Column 3 limits the sample to survey participants only. The first two columns indicate that each additional 10 years of age is associated with 1.2 percentage points more of their salaries being contributed to their DC accounts, but men contribute 0.2 percentage points less. Those earning more also contribute a higher share of their pay, and this effect is statistically significant. Including a control for who took the survey/educational module in Column 2 indicates that individuals who answer the survey contribute about 1 percentage point more of their salaries, as compared to their non-respondent counterparts; the other coefficients are not affected by the inclusion of this additional variable. Finally, in the subsample of survey respondents, we see that being more financially literate is associated with a higher contribution rate to these plans. Individuals that correctly answer 4-5 of the financial questions contribute 2.6 percentage points more of their earnings to the DC plan relative to employees with $0-1$ correct answer and those who answer 2-3 questions correctly contribute 1.4 percentage points more of their earnings.

\section{Table 4 here}

${ }^{10}$ Simon, Warner, and Pleeter (2015) extend the analysis of financial decisions by incorporating cognition, financial literacy, and personal discount rates in the choice of retirement plan distributions. They conclude their analysis by stating that "More work is needed to examine the link between cognition, financial literacy, and investment choices. Hopefully, too, subsequent surveys will contain questions to elicit information about financial literacy." Our survey of FR employees provides new evidence on financial literacy and how it influences retirement saving decisions. 
It is also of interest to evaluate whether financially knowledgeable DC plan participants invest differently from their counterparts. To examine diversification, we have classified each available fund on the DC plan menu according to its equity holdings. Next, we compute each person's stock exposure as a function of his allocation to each of the different funds. Table 5 shows, in the full sample, men hold more of their retirement savings in equities, and an additional $\$ 10,000$ in annual earnings increases the equity share by 1.4 percentage points. As expected, older workers favor less risky portfolios: an additional 10 years of age is associated with 5.7 percentage points less in risky investments. Once again, including a control variable indicating survey participation has only a modest impact on other estimated coefficients. Survey respondents held 3.7 percentage points more of their assets in equities. This result suggests that individuals who completed the financial literacy module may have gained a better understanding of investment risk and return. In the final column of Table 5, we report estimates on the subset of survey respondents. Here we find that coefficient estimates are very similar to the full sample. Additionally, we learn that someone measured as highly financially knowledgeable has 14.6 percentage points more of his retirement assets in equities compared to the least savvy. ${ }^{11}$ Even those with intermediate knowledge hold more in stocks than those who are less financially knowledgeable.

\section{Table 5 here}

In sum, our analysis of the pre-survey DC plan contributions and holdings yields several insights into these employees' DC plan behaviors. First, a relatively large share of Federal Reserve employees -84 percent - participates in the DC plan, and those who do contribute an average of almost 9 percent of their pay. Older and married employees are more likely to

\footnotetext{
${ }^{11}$ A more detailed analysis of how financial literacy influences portfolio outcomes is taken up in Clark, Lusardi and Mitchell (2014).
} 
participate and contribute, while men participate and contribute less than women. Overall, this employee population holds about 57 percent of its retirement assets in equities, with older workers holding slightly less, and men, married, and particularly the higher-paid workers taking riskier positions.

Second, we see that those employees who responded to our survey/module are 6 percentage points more likely than their nonrespondent counterparts to participate in the plan, contribute a percentage point more of their pay, and hold 4 percentage points more equity. The fact that the survey/module respondents differ somewhat from the non-respondent workforce indicates a degree of self-selection. And finally, people scoring the best on the financial knowledge survey/module are even more likely to participate in the plan, contribute even more of their salaries, and hold even more equity in their retirement accounts.

\section{Changes in Retirement Saving}

Next we evaluate whether there were marked changes in retirement plan patterns after the survey/module was fielded, drawing on additional administrative data on participation, contributions, and investment allocations gathered a year after the initial information examined above. This pre/post sample includes 20,867 individuals for whom we have retirement saving data for both the pre-survey wave in 2013 and six months after the completion of the educational module in 2014. Of these employees, 17,538 contributed to the DC plan and 3,329 did not, in 2013.

Our next analysis examines factors associated with the probability that a participant contributing to the DC plan at baseline stopped contributing one year later; results appear in Column 1 of Table 6 . Here we see that 7.1 percent of plan participants in the prior year stopped 
contributing to the plan a year later. Married employees and the higher earners were less likely to stop contributing, while those with more tenure and older were more likely to have stopped contributing. Employees who completed the financial literacy module were 4 percentage points less likely to have stopped contributing to the plan between 2013 and 2014 suggesting that completing the educational module encouraged employees to remain in the plan.

\section{Table 6 here}

The second column in Table 6 examines whether employees in 2013 not contributing to the DC plan had begun contributing a year later. In all, 11.6 percent of the nonparticipants in 2013 did contribute a year later, and interestingly, individuals who completed our financial literacy survey/module were 4.6 percentage points more likely to have started contributing to the DC plan, relative to those who did not. By this measure, the financial literacy survey/module had a significant positive effect on employee retirement saving. We also find that older employees not enrolled in 2013 were less likely to begin contributing, as were workers with more years of service. By contrast, more highly-paid employees were more likely to have enrolled a year later.

In summary, individuals who completed the module were more likely to start contributing and less likely to have stopped contributing to the DC plan, compared to their

nonrespondent counterparts. This suggests that having participating in the survey/module had a positive effect on DC plan behavior.

\section{Discussion and Implications}

Our analysis of administrative records provided by the OEB of the Federal Reserve paints a clear picture of the retirement saving behavior of current Federal Reserve employees. While this remains a case study, several lessons may be drawn. First, even given the fact that this 
employee group is covered by a defined benefit plan, a high fraction of the workers still participates in and contributes to the plan, though by no means is participation universal. Second, and as in other studies, we find that marital status, salary, tenure, and financial literacy are all predictors of participation and contribution levels to the firm's DC plan. Third, employees' levels of financial literacy are quite high compared to the general population, though we can measure it for only the subset of workers responding to the survey/module. Fourth, more financially knowledgeable employees are more likely to participate in their retirement saving plan, contribute more of their salaries, and hold more equity in their DC retirement accounts.

Finally, there remain areas for improvement. For example, fewer than half of the respondents to the survey were knowledgeable about the tax-deferred aspect of their DC plan contributions. Accordingly, targeted information and education on this important aspect of retirement saving may be beneficial to the workforce and help employees make better retirement saving decisions. Also, since there were no negative impacts of exposing savers to more information and education, programs intended to boost retirement saving could be of substantial value - particularly if participation in the modules were incentivized by and/or encouraged more robustly. 


\section{References}

Allen, Steven, Robert Clark, Jen Maki, and Melinda Morrill. 2013. Golden Years or Financial Fears: How Plans Change After Retirement Seminars. NBER Working Paper 19231.

Bayer, Patrick, Douglas Bernheim, and John Karl Scholz. 2009. The Effects of Financial Education in the Workplace: Evidence from a Survey of Employers. Economic Inquiry 47(4): 605-624.

Bernheim, Douglas, and Daniel Garrett. 2003. The Effects of Financial Education in the Workplace: Evidence from a Survey of Households. Journal of Public Economics 87: 1487-1519.

Clark, Robert, Madeleine d'Ambrosio, Ann McDermed, and Kshama Sawant. 2006. Retirement Plans and Saving Decisions: The Role of Information and Education. Journal of Pension Economics and Finance: $45-67$.

Clark, Robert, Melinda Morrill, and Steven Allen. 2012a. Effectiveness of Employer-Provided Financial Information: Hiring to Retiring. American Economic Review. May: 314-31.

Robert Clark, Melinda Morrill, and Steven Allen. 2012b. The Role of Financial Literacy in Determining Retirement Plans. Economic Inquiry, October: 851-866.

Clark, Robert, Annamaria Lusardi, and Olivia S. Mitchell. 2014. Financial Knowledge and 401(k) Investment Performance. NBER Working Paper n. 20137.

Clark, Robert, Jennifer A. Maki, and Melinda Sandler Morrill. 2014. Can Simple Informational Nudges Increase Employee Participation in a 401(k) Plan? Southern Economics Journal. 80(3): 677-701.

Consumer Financial Protection Bureau. 2014. Financial Wellness at Work: A Review of Promising Practices and Policies. August. http://files.consumerfinance.gov/f/201408_fpb_report financialwellness-at-work.pdf

Lusardi, Annamaria. 2011. Americans' Financial Capability. NBER Working Paper 17103.

Lusardi, Annamaria, and Olivia S. Mitchell. 2014. The Economic Importance of Financial Literacy: Theory and Evidence. Journal of Economic Literature. 52(1): 5-44.

Lusardi, Annamaria, and Olivia S. Mitchell. 2011a. Financial Literacy and Planning: Implications for Retirement Wellbeing. In Financial Literacy: Implications for Retirement Security and the Financial Marketplace. Eds. O. S. Mitchell and A. Lusardi. Oxford, Oxford University Press: 1739.

Lusardi, Annamaria and Olivia S. Mitchell. 2011b. Financial Literacy and Retirement Planning in the United States. Journal of Pension Economics and Finance 10(4): 509-525.

Lusardi, Annamaria and Olivia S. Mitchell. 2011c. Financial Literacy around the World: An Overview. Journal of Pension Economics and Finance 10(4): 497-508.

Lusardi, Annamaria, and Olivia S. Mitchell. 2009. How Ordinary Consumers Make Complex Economic Decisions: Financial Literacy and Retirement Readiness. NBER Working Paper 15350.

Lusardi, Annamaria and Olivia S. Mitchell. 2008. Planning and Financial Literacy: How Do Women Fare? American Economic Review 98:2, 413-417.

Lusardi, Annamaria and Olivia S. Mitchell. 2007. Financial Literacy and Retirement Preparedness. Evidence and Implications for Financial Education. Business Economics, January: 35-44.

Lusardi, Annamaria, Olivia S. Mitchell, and Vilsa Curto. 2010. Financial Literacy among the Young. Journal of Consumer Affairs. 44(2): 358-380.

Simon, Curtis John Warner, and Saul Pleeter. 2015. Discounting, Cognition, and Financial Awareness: New Evidence from a Change in the Military Retirement System, Economic Inquiry, 53(1): 318334. 


\section{Table 1. Comparison of Observables for Survey/Module Respondents and Nonrespondents}

This Table summarizes key variables for all 2013 Fed employees, 401(k) plan participants who responded to the Financial Knowledge questions in the survey/module, as well as for those who did not. All data are taken from the institution's administrative records, and refer to active employees (i.e., not retired, vested terminated, or deceased).

Diff.

(Nonpart.- T-test for

\begin{tabular}{lccccl} 
Variable & Total & Nonrespondents & Respondents & Part.) & significance \\
\hline \% Participants in Pretax Only & 66.86 & 66.39 & 69.41 & -3.02 & $* * *$ \\
\% Participants in Roth Only & 8.13 & 7.97 & 9.00 & -1.03 & $*$ \\
\% Participants in Both & 8.96 & 8.53 & 11.20 & -2.67 & $* * *$ \\
\% Salary Contribution & 7.32 & 7.00 & 9.02 & -2.02 & $* * *$ \\
Total balance (\$100k), Pretax Only & 1.51 & 1.37 & 2.26 & -0.89 & $* * *$ \\
\% Balance in equity, Pretax Only & 52.54 & 52.16 & 54.56 & -2.40 & $* * *$ \\
\% Contribution in equity & 57.19 & 56.89 & 58.66 & -1.77 & $* *$ \\
Age & 44.34 & 43.67 & 47.90 & -4.22 & $* * *$ \\
Male & 0.57 & 0.57 & 0.57 & 0.00 & \\
Married & 0.62 & 0.60 & 0.69 & -0.08 & $* * *$ \\
Salary (\$10k) & 9.82 & 9.68 & 10.55 & -0.87 & $* * *$ \\
Tenure (years) & 12.26 & 11.78 & 14.83 & -3.05 & $* * *$ \\
\hline $\mathrm{N}$ & 21,192 & 17,835 & 3,357 & &
\end{tabular}

Note: *** Significant at the 0.01 level; ** Significant at the 0.05 level; * Significant at the 0.10 level. 
Table 2. Results of Financial Knowledge Assessment

\begin{tabular}{|c|c|c|}
\hline Financial Knowledge Questions: & $\begin{array}{l}\text { \% with } \\
\text { correct } \\
\text { answers }\end{array}$ & S.D \\
\hline $\begin{array}{l}\text { Suppose you had } \$ 100 \text { in a savings account and the interest rate was } 2 \% \text { per } \\
\text { year. After } 5 \text { years, how much do you think you would have in the account if } \\
\text { you left the money to grow? More than } \$ 110 \text {, Exactly } \$ 110 \text {, Less than } \$ 110 \text {, } \\
D K, R F\end{array}$ & 0.75 & 0.44 \\
\hline $\begin{array}{l}\text { Imagine that the interest rate on your savings account was } 1 \% \text { per year and } \\
\text { inflation was } 2 \% \text { per year. After } 1 \text { year, how much would you be able to buy } \\
\text { with the money in this account? More than today, Exactly the same, Less than } \\
\text { today, } D K, R F\end{array}$ & 0.91 & 0.29 \\
\hline $\begin{array}{l}\text { True or False? Buying a single company's stock usually provides a safer return } \\
\text { than a stock mutual fund. True, False, } D K, R F\end{array}$ & 0.85 & 0.35 \\
\hline $\begin{array}{l}\text { Assume you were in the } 25 \% \text { tax bracket (you pay } \$ 0.25 \text { in tax for each dollar } \\
\text { earned) and you contributed } \$ 100 \text { pretax to an employer's } 401(\mathrm{k}) \text { plan. Your } \\
\text { take-home pay (what's in your paycheck after all taxes and other payments are } \\
\text { taken out) will then: Decline by } \$ 100 \text {, Decline by } \$ 75 \text {, Decline by } \$ 50 \text {, Remain } \\
\text { the same, } D K, R F\end{array}$ & 0.43 & 0.50 \\
\hline $\begin{array}{l}\text { Assume that an employer matched employee contributions dollar for dollar. If } \\
\text { the employee contributed } \$ 100 \text { to the } 401(\mathrm{k}) \text { plan, his account balance in the } \\
\text { plan including his contribution would: Increase by } \$ 50 \text {, Increase by } \$ 100 \text {, } \\
\text { Increase by } \$ 200 \text {, Remain the same, DK, RF }\end{array}$ & 0.76 & 0.43 \\
\hline Financial Knowledge Index (number of ques & 3.71 & 1.23 \\
\hline
\end{tabular}

Note: DK refers to "do not know" and RF to "refuse to answers". 
Table 3. Determinants of Pension Participation: All Employees, April 2013

Probit models, marginal effects reported.

Age

Male

Married

Salary $(\$ 10 \mathrm{k})$

Tenure

Finlit survey

Mid Fin. Literacy Index (2-3)

High Fin. Literacy index (4-5)

\begin{tabular}{ccc}
$\begin{array}{c}\text { Full } \\
\text { sample }\end{array}$ & $\begin{array}{c}\text { Full } \\
\text { sample }\end{array}$ & $\begin{array}{c}\text { Surveyed in } \\
2013\end{array}$ \\
\hline 0.0004 & 0.0002 & 0.0004 \\
$(0.0003)$ & $(0.0003)$ & $(0.0006)$ \\
$-0.0199 * * *$ & $-0.0191 * * *$ & -0.0044 \\
$(0.0047)$ & $(0.0047)$ & $(0.0093)$ \\
$0.0094 *$ & $0.0090 *$ & 0.0037
\end{tabular}

$\begin{array}{lll}(0.0051) & (0.0051) \quad(0.0101)\end{array}$

$0.0183 * * * \quad 0.0177 * * * \quad 0.0078 * * *$

$\begin{array}{lll}(0.0007) & (0.0007) \quad(0.0015)\end{array}$

$-0.0080 * * * \quad-0.0080 * * * \quad-0.0045 * * *$

$\begin{array}{lll}(0.0003) & (0.0003) \quad(0.0005)\end{array}$

$0.0627 * * *$

$(0.0054)$

$0.0675 * * *$

$(0.0122)$

$0.1343 * * *$

$(0.0225)$

\begin{tabular}{lrrr}
\hline $\mathrm{N}$ & 21,192 & 21,192 & 3,357 \\
$\mathrm{R}$-square & 0.142 & 0.147 & 0.133 \\
Mean of dep var & 0.840 & 0.840 & 0.896 \\
St.dev of dep var & 0.367 & 0.367 & 0.305 \\
Note: $* \mathrm{p}<0.10, * * \mathrm{p}<0.05, * * * \mathrm{p}<0.01$ & &
\end{tabular}


Table 4. Determinants of Employee Contributions in 2013 (as a \% of salary) OLS models

Age

Male

Married

Salary $(\$ 10 \mathrm{k})$

Tenure

Finlit survey

Mid Fin. Literacy Index (2-3)

High Fin. Literacy index (4-5)

\begin{tabular}{lrrr} 
& & $(0.0055)$ \\
\hline $\mathrm{N}$ & 17,791 & 17,791 & 3,008 \\
$\mathrm{R}$-square & 0.073 & 0.078 & 0.064 \\
Mean of dep var & 0.087 & 0.087 & 0.101 \\
St.dev of dep var & 0.057 & 0.057 & 0.062 \\
Note: $* \mathrm{p}<0.10, * * \mathrm{p}<0.05, * * * \mathrm{p}<0.01$ & &
\end{tabular}

$0.0143 * *$

$(0.0057)$

$0.0255 * * *$

$(0.0001) \quad(0.0001) \quad(0.0002)$

$0.0001 \quad 0.0000 \quad 0.0002 *$

$\begin{array}{lll}(0.0001) & (0.0001) \quad(0.0001)\end{array}$

$0.0104 * * *$

$(0.0012)$
Note: $p<0.10, * * p<0.05, * * * p<0.01$ 
Table 5. Determinants of Portfolio Share in Equities: Employees in 2013 OLS models

\begin{tabular}{lccc} 
& $\begin{array}{c}\text { Plan } \\
\text { participants }\end{array}$ & $\begin{array}{c}\text { Plan } \\
\text { participants }\end{array}$ & $\begin{array}{c}\text { Surveyed \& in } \\
\text { plan in 2013 }\end{array}$ \\
\cline { 2 - 4 } Age & $-0.0057 * * *$ & $-0.0058 * * *$ & $-0.0065 * * *$ \\
& $(0.0002)$ & $(0.0002)$ & $(0.0006)$ \\
Male & $0.0498 * * *$ & $0.0497 * * *$ & $0.0393 * * *$ \\
& $(0.0043)$ & $(0.0043)$ & $(0.0108)$ \\
Married & $0.0160 * * *$ & $0.0159 * * *$ & $0.0230 * *$ \\
& $(0.0047)$ & $(0.0047)$ & $(0.0117)$ \\
Salary (\$10k) & $0.0139 * * *$ & $0.0137 * * *$ & $0.0070 * * *$ \\
& $(0.0005)$ & $(0.0005)$ & $(0.0014)$ \\
Tenure & $-0.0035 * * *$ & $-0.0035 * * *$ & $-0.0033 * * *$ \\
& $(0.0003)$ & $(0.0003)$ & $(0.0006)$ \\
Finlit survey & & $0.0369 * * *$ & \\
Mid Fin. Literacy Index $(2-3)$ & & $(0.0059)$ & \\
High Fin. Literacy index $(4-5)$ & & & $0.0559 * *$ \\
& & & $(0.0264)$ \\
\hline N & & & $0.1463 * * *$ \\
R-square & & & $(0.0260)$ \\
Mean of dep var & 17,791 & 17,791 & 3,008 \\
St.dev of dep var & 0.107 & 0.109 & 0.146 \\
Note: $*$ p $<0.10, * * p<0.05, * * *$ & $p<0.01$ & 0.572 & 0.587 \\
& 0.572 & 0.298 & 0.302 \\
& 0.298 & &
\end{tabular}


Table 6. Probability of Stopping or Starting Contributions in 2014, Relative to 2013

Probit models, marginal effects reported

\begin{tabular}{lc|c} 
& $\begin{array}{c}\text { Stop participating } \\
\text { Plan } \\
\text { participants in } \\
2013\end{array}$ & $\begin{array}{c}\text { Start participanting } \\
\text { Non- } \\
\text { participants in } \\
2013\end{array}$ \\
\cline { 2 - 3 } Age & $0.0005 * *$ & $-0.0021 * * *$ \\
Male & $(0.0002)$ & $(0.0005)$ \\
& $0.0129 * * *$ & $-0.0167 *$ \\
Married & $(0.0038)$ & $(0.0085)$ \\
Salary (\$10k) & $-0.0189 * * *$ & -0.0002 \\
Tenure & $(0.0042)$ & $(0.0087)$ \\
& $-0.0021 * * *$ & $0.0061 * * *$ \\
Finlit survey & $(0.0005)$ & $(0.0010)$ \\
& $0.0008 * * *$ & $-0.0050 * * *$ \\
N & $(0.0002)$ & $(0.0005)$ \\
R-square & $-0.0377 * * *$ & $0.0463 * * *$ \\
Mean of dep var & $(0.0041)$ & $(0.0177)$ \\
St.dev of dep var & 17,538 & 3,329 \\
Note: $*$ p $<0.10, * * \mathrm{p}<0.05, * * * \mathrm{p}<0.01$ & 0.168 \\
& 0.018 & 0.116 \\
& 0.071 & 0.320
\end{tabular}

